\title{
Archipel
}

ARCHIPEL Études interdisciplinaires sur le monde insulindien

$89 \mid 2015$

Varia

\section{Dialog, Kritik, Mission Franz Magnis-Suseno, Ein indonesischer Jesuit aus Deutschland}

\section{Marlies Salazar}

\section{(2) OpenEdition}

1 Journals

\section{Édition électronique}

URL : http://journals.openedition.org/archipel/509

DOI : $10.4000 /$ archipel. 509

ISSN : 2104-3655

\section{Éditeur}

Association Archipel

\section{Édition imprimée}

Date de publication : 15 avril 2015

Pagination : 209-2011

ISBN : 978-2-910513-72-6

ISSN : 0044-8613

\section{Référence électronique}

Marlies Salazar, « Dialog, Kritik, Mission Franz Magnis-Suseno, Ein indonesischer Jesuit aus Deutschland ", Archipel [En ligne], 89 | 2015, mis en ligne le , consulté le 05 mars 2021. URL : http:// journals.openedition.org/archipel/509; DOI : https://doi.org/10.4000/archipel.509

Ce document a été généré automatiquement le 5 mars 2021.

Association Archipel 


\title{
Dialog, Kritik, Mission Franz Magnis-Suseno, Ein indonesischer Jesuit aus Deutschland
}

\author{
Marlies Salazar
}

\section{RÉFÉRENCE}

Heinz SCHÜTTE, Dialog, Kritik, Mission Franz Magnis-Suseno, Ein indonesischer Jesuit aus Deutschland, Regiospectra Verlag, Berlin, 2013, 225 mm x 155 mm, xii + 447 p., ill. ISBN 978-3-940132-61-1

1 This biography of Fr. Franz Magnis Suseno SJ, an Indonesian Jesuit from Germany was written by Heinz Schütte, a German social scientist at the suggestion of Franz Xaver Augustin, the regional director of the Goethe Institutes in South-East Asia. Although Fr. Magnis has lived more than fifty years in Indonesia and is an important public figure, so far no biography had been written about him. The University of Bonn only wanted to collect his papers and publications as research material for its students. Fortunately Schütte has taken it upon himself to read the thousands of letters of Fr. Magnis and to interview friends and members of his family. The result is a vivid picture of this extraordinary man who devoted his entire adult life to his adopted country, Indonesia.

Franz Magnis-Suseno was born in 1936 in Silesia (then Germany, now Poland) as Franz Count von Magnis, the eldest son of a noble family. The whole family had to flee from Silesia at the end of World War II and settled in West Germany under rather difficult circumstances. Franz went to a Jesuit boarding school and decided to become a Jesuit at the age of 10. After his novitiate and the study of philosophy, he decided in 1961 to join the Jesuit mission in Indonesia. It was love at first sight. He started by learning Javanese and immersed himself in the Javanese culture. He learned Indonesian later when he spent some time in Jakarta. From 1964 to 1968 he studied theology in Yogyakarta, where most of his classmates were Javanese. During this time the events of 1965 
occurred-the military putsch and the ensuing massacre. Although Magnis was appalled by the killing of hundreds of thousands of alleged communists, he felt that as a non-Indonesian he could do little about it. He noticed, however, that in central Java many people converted to the Christian faith, since the church started to take care of political prisoners and their families from 1966 on. Magnis baptized many people and taught catechism in a prison. In July 1967 Magnis was ordained as a priest in Semarang and in August he held his first sermons in Javanese in Yogyakarta. After finishing his studies of theology he was sent to Jakarta to organize the new Jesuit University of Philosophy, the Sekolah Tinggi Filsafat (STF) Driyarkara, named after the philosopher and Jesuit Nicolaus Driyarkara (1913-1967). From the very beginning its aim was to become a platform for a dialogue between different religions and worldviews. Fr. Magnis spent three years organizing the new college and teaching. Then in 1971 he went to the University of Munich to prepare his doctorate. Since his earlier studies he had been fascinated by Marxism and wrote his doctoral thesis on "Normative Presuppositions in the thought of the young Marx", demystifying Marx. This dissertation was published in Germany in 1975, but never translated into Indonesian. Upon his return to Indonesia Fr. Magnis was considered as a specialist in Marxism, which since the events of 1965 was a taboo. But in 1975 an institute close to the government and the military, the CSIS (Center for Strategic and International Studies), asked him to write an article about Marxism and Communism for their journal Prisma. It was published only in English, because it was considered too controversial for the Indonesian edition. It was later integrated into Magnis' course on "Social Philosophy in $19^{\text {th }}$ Century Germany." Copies of it circulated among the students and some were sentenced to prison for owning it. Later in 2001 radical Muslims burned his books on Marxism. Fr. Magnis condemned this on TV and in newspapers, likening it to the burning of books by the Nazis in 1933. He found it rather foolish, because the students burnt books that were actually critical of Marx. They couldn't distinguish between leftists and people analyzing leftist ideas.

In $1977 \mathrm{Fr}$. Magnis became an Indonesian citizen and added Suseno to his name. Suseno is part of the Javanese wayang tradition and this change of name shows the willingness of Fr. Magnis to adapt to the culture of his adoptive country. He was especially fascinated by the Javanese tradition and published in 1981 his first book on Javanese Wisdom and Ethics. From the very beginning of his stay in Indonesia he had admired the relaxed politeness and graciousness of the Javanese, but also wondered about their reserved and mysterious behavior. He wanted to understand the ethic norms of the Javanese and compare them with European traditions. Fr. Magnis' description of Javanese culture and ethics is an important contribution to our knowledge of Javanese culture and to intercultural dialogue. At the same time it opened the eyes of many Javanese intellectuals to their own culture and their ideas of a Good Life. But the social harmony it describes seems to be an ideal prototype, because there has been a lot of violence in Indonesian history. And the question remains open whether it can really be applied to all the diverse cultural groups of Indonesia and to a changing Indonesian society.

4 The biographer interrupts the flow of the biography of Fr. Magnis with sketches of other people more or less close to him, like his aunt Gabriele who helped Jews and communists under the Nazi regime, or his youngest sister Bernadette who, as a student in Bonn, became a Maoist. Two other sketches are about Jesuits who chose a different approach to the problems of Indonesia: Fr. Josephus Beek, a Dutch Jesuit who became a kind of grey eminence under the Soeharto regime and trained cadres for important 
positions in the society of his authoritarian corporatist government. The other is Fr. Werner Ruffing, a German Jesuit who chose to live amongst the most disadvantaged people, first in a leper colony and then volunteered to live as a missionary among the political prisoners on the remote island of Buru in the Moluccas. Because he openly criticized the terrible living conditions there, the Indonesian government declared him a persona non grata. He died in Brazil in 1984.

Maybe Schütte wanted to show the life of these people as a contrast to the brilliant academic career of Fr. Magnis, who has written about 30 books and more than 500 articles while teaching for more than 40 years and administering the STF Driyarkara. But Fr. Magnis is not an aloof academic. He has lived in Indonesia from 1961 up to now and experienced the "Guided Democracy" of president Sukarno, the coup of 1965 and the ensuing massacre, the "New Order" of president Soeharto from 1966 to 1998, the short-lived presidencies of Habibie, Gus Dur, of Megawati Sukarnoputri, the presidency of Yudoyono (2004-2014) and now the newly elected president Joko Widodo. If at the beginning Fr. Magnis was only a prudent observer, he has become more and more a sharp-minded analyst of Indonesian society and politics, and now he is quite outspoken, but always with a profound sympathy for the country and its people.

Magnis has considerable experience not only in the area of intercultural, but also of religious dialogue. He was the first Jesuit in Indonesia who, in the wake of Vatican Council II, sought contact with Muslim intellectuals. In 1973 he asked the student leader and theologian Nurcholish Madjid to teach Islamology at the STF Driyarkara. Nurcholish demanded a secularized Islam and developed an integrative theology. Fr. Magnis also befriended Abdurrahman Wahid, the leader of Nahdlatul Ulama, Indonesia's largest Muslim organization, who called himself Gus Dur, and the scholar Djohan Effendi. In 1991 he got involved in the "Democratic Forum", which brought together Muslims, Catholics, Protestants, Hindus and Buddhists, in a discussion on how a democratic society could be realized in Indonesia. Fr. Magnis has turned into a public intellectual who takes part in seminars, lectures and discussions on TV. He wants to promote dialogue, democracy and the recognition of cultural and religious differences in Indonesia. Even after his retirement from administrative duties at the STF Driyarkara he continues teaching and is still responsible for the post-graduate program.

7 Schütte has painted a portrait of Fr. Magnis not only as an intellectual and a man of faith, but also as a human person with a love of mountaineering and good food. But Schütte's tendency to project himself into the biography of Fr. Magnis with his own problems diverts the reader's attention from the subject. Schütte confesses towards the end of the biography "Ich habe dieses Buch in erster Linie zu meinem plaisir geschrieben-eine Sache des Sicherkennens über den Umweg der Entdeckung eines Anderen." "I have written this book mostly for my own pleasure, to become conscious of myself-a way of knowing oneself by the detour of discovering somebody else.") Another shortcoming of the book is that Schütte, as he admits himself, is not a specialist on Indonesia. His interest in Indonesia is quite recent and he cannot read the many publications that Fr. Magnis has written in Indonesian. It would be good if someone more qualified-maybe an Indonesian-could throw light on this aspect of Fr. Magnis work and put it into an Indonesian context. 